\title{
The Rise of a New Tourism Dawn in the Middle East
}

\author{
Said Ladki, Anggito Abimanyu, Lara Kesserwan \\ Hospitality and Tourism Management Department, Lebanese American University, Beirut, Lebanon \\ Email: sladki@lau.edu
}

How to cite this paper: Ladki, S., Abimanyu, A., \& Kesserwan, L. (2020). The Rise of a New Tourism Dawn in the Middle East. Journal of Service Science and Management, 13, 637-648.

https://doi.org/10.4236/jssm.2020.134040

Received: May 20, 2020

Accepted: August 10, 2020

Published: August 13, 2020

Copyright $\odot 2020$ by author(s) and Scientific Research Publishing Inc. This work is licensed under the Creative Commons Attribution International License (CC BY 4.0).

http://creativecommons.org/licenses/by/4.0/

\begin{abstract}
This paper reports about the transformational changes that are taking place in the Middle East travel and tourism industries. Though some Middle Eastern countries are no longer dependent on religious tourism as their main driver; across the region, new diversified tourism portfolios are being developed. This paper reports about the Kingdom of Saudi Arabia's (KSA) existing and new tourism products, introduces the tourism offerings of selected neighboring Middle Eastern countries and identifies the challenges confronting the Middle East travel and tourism industries.
\end{abstract}

\section{Keywords}

Tourism, Religious Tourism, Tourism Portfolios, Middle East

\section{Introduction}

This paper reports about the dynamic changes of the Middle East travel and tourism industry. According to the president of the World Religious Travel Association (WRTA), "the Middle East is the world's largest driver of religious travel; with the sector fueling the region's current tourism growth by 11 percent annually" ("300m Religious Tourists in the Middle East", 2014). Although religious tourism represents a considerable source of income for selected Middle Eastern countries, in recent years; new forms of tourism products have been introduced and successfully attracted new travelers to the region (King, 2018).

The overall revenue of the region's religious tourism is around $\$ 12$ billion per year (King, 2018). KSA and Iraq are the two Middle Eastern nations that are homes for the holiest Islamic sites. Annually, KSA welcomes around 17.5 million religious tourists; whereas, Iraq receives 22 million (Twaij, 2016). To accommodate the constant growth in the numbers of arrivals, KSA and Iraq plan to expand their holy cities (KSA: Mecca and Medina; Iraq: Karbala and Najaf) to 
welcome 30 million pilgrims.

Likewise, the United Arab Emirates (UAE) and Iran are also regional religious tourism centers that are witnessing an increase in their number of arrivals. In 2003, Iran welcomed around 3 million individuals who have visited religious sites in the cities of Mashhad and Qom. By 2016, the number of religious visitors to Mashhad has reached 28 million ("Mashhad More than a Religious Destination", 2017). The UAE's intention in becoming a hub for interreligious dialogue and peaceful coexistence lead to the building of a 158-acre Quranic theme park, which is expected to be operational by 2020 (Gillett, 2019). Further, in April 2019, the UAE has laid the foundation stone to build the country's first traditional Hindu Temple (Badam, 2019). Currently, plans are underway to complete the construction of the first synagogue in the Arab world. The synagogue which is expected to be inaugurated in 2022 will be part of Abu Dhabi's multifaith complex ("UAE's First Official Synagogue", 2019) (Figure 1).

KSA vision 2030 recognizes the importance of tourism. The nation is easing the entry barriers and opening itself to foreign tourists. KSA is developing new tourism attractions, coastal cities; resort towns; theme parks; and indigenous; environmental and cultural events. Once developed, such tourism assets will complement the tourism product offerings of Jordan, Qatar, Dubai, and Abu Dhabi. Being a regional powerhouse, KSA is currently positioning itself as the Middle East leader in religious and sports tourism. Capitalizing on its success in holding world-class international sporting events, KSA hosted the fifth season of Formula E Championship (Formula E-Season 2018-2019) which is the highest class competition for electric open-wheel car racing; and the Red Bull Air which enabled more than 60,000 Saudi fans to witness the race ("Thousands Flock to Dammam Demo", 2019). Further, KSA has informed the Asian World Cup authorities of its intention to host the 2027 event in the kingdom (Mohiedin, 2020).

A new dawn of tourism is rising in the Middle East. The new dawn capitalizes on the region's religious assets and introduces new tourism products which are certainly changing the landscape and bring new tourists to the region.

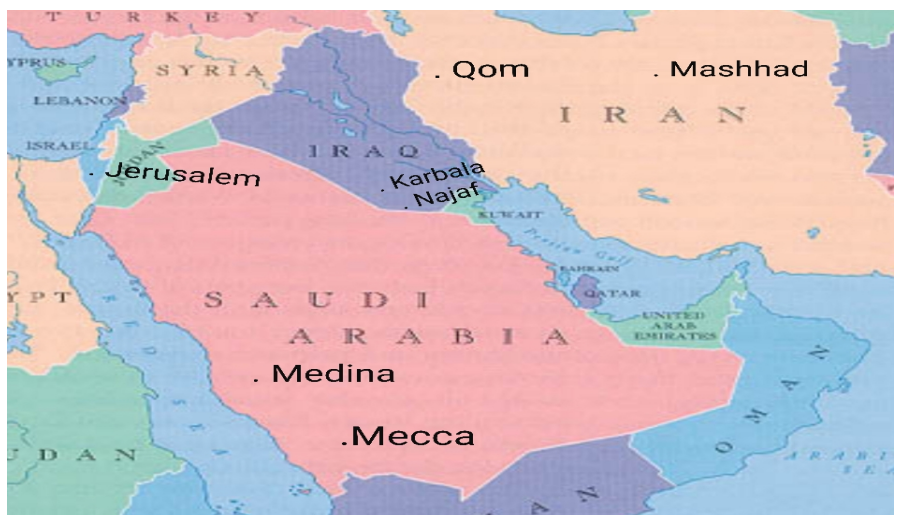

Figure 1. Muslim holy sites. Source: https://www.pbs.org/wnet/wideangle/uncategorized/who-are-the-shi a-shia-holy-cities/1735/. 


\section{Literature Review}

Religious tourism is an old form of tourism (Tala \& Padurean, 2008; Kapur, 2018). The history of pilgrimages and religious tourism can be traced from its beginnings; through the Middle Ages; to the present-day. Unlike other forms of tourism, religious tourism does not incorporate any worldly entertainment. It is a kind of tourism that meets the spiritual and religious needs of people who travel individually or in groups for pilgrimage, or fellowship purposes (Kocyigit, 2016).

\subsection{Religious Tourism in Saudi Arabia}

The city of Mecca is ranked 13 as the most visited cities in the world (Millington, 2019). KSA's holy cities of Mecca and Medina are located in the Western Region of the Kingdom and are homes to the most important mosques in the Islamic World; specifically, the Great Mosque of Mecca (Al Masjid Al Haram) and the Mosque of the Prophet (Al Masjid Al Nabawi). Mecca's mosque is in the city of Mecca which was the birthplace of prophet Muhamad. The mosque, which was built in 638 A.D., has witnessed numerous expansions and renovation initiatives over the years. The mosque's total current indoor and outdoor space is about 99 acres (Al Serkal, 2019).

The mosque houses the Black Stone, which is a cornerstone and an integral part of the Kaaba's reconstructed wall, built by prophet Muhammad before his first revelation ("Revealed: The World's 20 Most Expensive Buildings", 2016) (Figure 2). The mosque is annually visited by four million people who are eager to fulfill their pilgrimage which is known as (Hajj) ("Revealed: The World's 20 Most Expensive Buildings", 2016). Hajj is considered to be one of the fifth pillars of Islam. Hajj revenues contribute 20 percent of the kingdom's non-oil GDP and 7 percent of total GDP (King, 2018). An additional 13.5 million people visit Mecca's mosque during OFF Hajj season to perform Umrah (an optional religious visit to the holy sites). Umrah visitors are still required to visit Mecca once in a lifetime to fulfill Hajj obligations. While in KSA all Hajj and Umrah visitors stopover at the mosque of the Prophet, which is located in Medina. The mosque is the most revered in Islam. It is home to Prophet Muhamad's tomb and was built in 622 A.D.

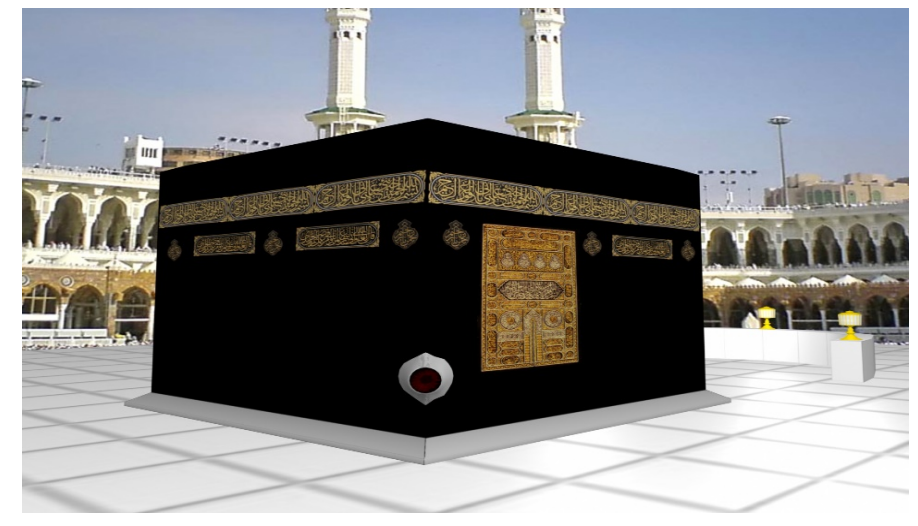

Figure 2. Kaaba's black stone. 
The constant growth in the numbers of religious tourists compelled KSA authorities to provide world-class hospitality services to all pilgrims. For almost 1400 years, Muslim pilgrims have joined caravans, saddled up horses, set off on foot, or boarded boats for Mecca (Frost, 2019). Today, they are making the same journey, but their visit is faster, safer, and more efficient. However, the 99 acre Mecca great mosque could no longer accommodate the increasing number of arrivals ("Revealed: The World's 20 Most Expensive Buildings", 2016). The mosque existing carrying capacity may compromise visitor's safety, or prevent all those who want to visit the mosque from doing so at their schedule. Currently, not all those who want to visit Mecca during Hajj seasons are granted visas. The limited space of Mecca's great mosque is creating tension among Muslim states. All of the 49 Muslim majority countries (Desilver \& Masci, 2017) want to increase the number of issued visas, whereas; Saudi authorities are concerned about safety, security, and the visit's integrity, they continue to restrict the number of issued visas. For example, in December 2017, 2.2 million people in Indonesia applied for Hajj visas, and only 211,000 requests were approved (Jumali, 2018). Indonesian pilgrims wait an average of 17 years before their visa request is approved. The high demand and the long waiting period compelled Saudi authorities to expand and remodel the 99-acre mecca mosque (Frost, 2019) (Figure 3).

\subsection{The Middle East Most Visited Religious Sites}

The Middle East is home to the most important religious sites for $50 \%$ of the world population ("Major Religions of the World", 2017). All followers of Judaism, Christianity, and Islam consider Jerusalem as a holy city (Romain, Pepinster, \& Hasan, 2015). Though places of religious significance are dotted throughout the Middle East, some sites are more significant or more visited than others. Regardless of religious faith, or whether one is a believer or not, people from all of the world recognized 12 faiths (Baha'i, Buddhism, Christianity, Confucianism, Hinduism, Islam, Jainism, Judaism, Shinto, Sikhism, Taoism, and Zoroastrianism) ("Major Religions of the World", 2017) visit the Middle East religious sites (Table 1).

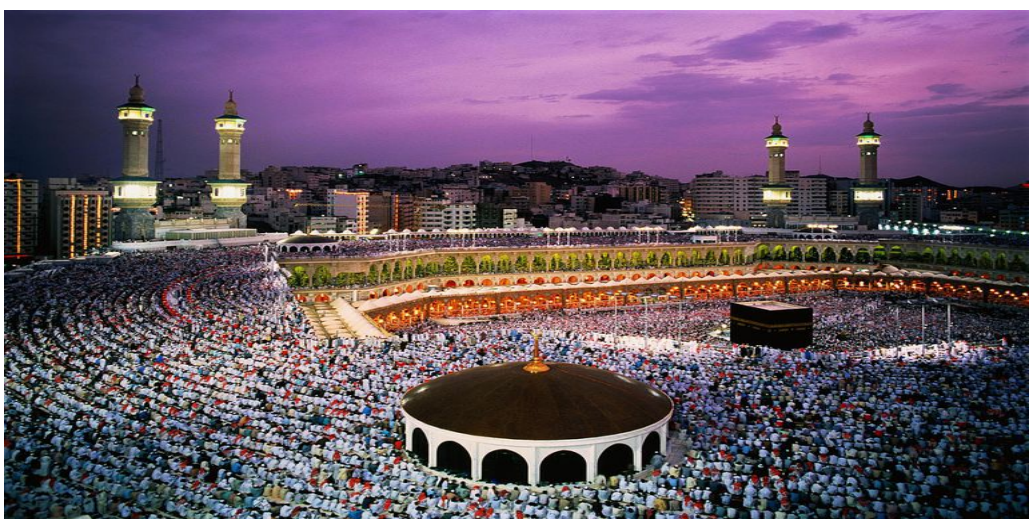

Figure 3. The 99 acre great mosque of mecca. 
Table 1. The middle east most visited religious sites.

The Great Mosque of Mecca-Mecca, KSA:

Considered to be the topmost important religious attraction for all of the 1.6 billion Muslims.

The Mosque of the Prophet-Medina, KSA:

Built by Prophet Mohammad and houses his tomb. It is the second most sacred place in Islam.

Mt Sinai and St. Catherine Monastery-Sinai, Egypt.

The full official name of the monastery is the God-Trodden Mount Sinai Sacred Monastery.

One of the world's oldest Christian monasteries, established between 548 and 565 .

Saidnaya-Syria:

Is the home of a traditionally held Greek Orthodox monastery established by Byzantine emperor Justinian I.

Mount Nebo-Jordan:

Believed to be the location where Moses stood before his death. (The Book of Deuteronomy)

Bethabara-Jordan:

The location is claimed to be the place where Jesus of Nazareth was baptized by John the Baptist.

Imam Ali Mosque-Najaf, Iraq:

Najaf is a holy Shi'a Muslim city in southern Iraq. To Shi'a Muslims (a sect of Islam), after Mecca and Medina, the Imam Ali Mosque in Najaf is the world's third most sacred shrine.

Imam Reza Shrine-Mashhad, Iran:

It is a place of prayers for Shiite Muslim.

Ephesus-Turkey:

It is of early Christian evangelism and continues to be an important archeological site and destination for Christian pilgrimage.

Al Aqsa Mosque-Jerusalem:

An important Islamic holy site situated in the Jerusalem Old City.

Church of the Holy Sepulchre, the Mount of Olives and the Via Dolorosa-Jerusalem: To Islam, the Mount of Olives is particularly important. The Mount is a 3000 years old Jewish cemetery.

Western Wall-Jerusalem:

A sacred place of prayer and pilgrimage for the Jewish people.

Source: https://scoopempire.com/fascinating-pilgrimage-sites-in-the-middle-east/.

The advent of transportation and hospitality technologies have enabled thousands of religious tourists to visit religious destinations. Religious tourism sites incorporate places of both religion and tourism dimensions. As an example, European monasteries are not only religious sites, but also they are places to enjoy serenity, nature, and environmental beauty and bounty (Cartwright, 2018). Likewise, Buddhist temples are situated in a magnificent structure surrounded by a tranquil environment that enables kindship with nature (Cassaniti, 2015: p. 59). Similarly, Uluru in Australia is a mythic sacred place for Aboriginals. It is recognized for its spectacular beauty. Annually, half a million pilgrims visit the Australian outback to look at the gigantic marker (Bremer, 2005). However, up to now; Mecca's strictly religious context kept the city away from mainstream travelers. Upon the implementation of vision 2030, Mecca may be opened to the world and all kinds of tourists. 


\section{Advancement in Islamic Tourism}

KSA has been aggressively implementing its 2030 Vision to transform the whole country. The Hajj Season represents a significant part of the vision. The vision has allocated to the country's travel and tourism sector $\$ 50$ billion worth of projects aiming to boost the number of Hajj and Umrah visitors. According to KSA Communications and Information Commission, preparations for the 2019 Hajj season were as follows: $5442 \mathrm{Wi}$-Fi access points, 44 MBPS Average of Mobile Download Speed, 37 5G Towers in the Holy Sites, and a 10\% increase in network capacity, which alone is a tremendous technological achievement ("CITC Deputy Governor", 2019). To monitor visitors' quality of life and safety, the authorities have established partnerships with world-renowned companies specializing in artificial intelligence, security, surveillance, sound, lighting, cleanliness, and maintenance systems. The Hajj pilgrims' e-bracelet program was initiated to provide pilgrims with selected services (Religious, medical, transportation, meals, etc.), and government agencies with information related to guest (country of origin, spoken language, point of entry, place of stay, length of stay, name and contact of travel wholesaler, blood type, immunization records, etc.) (Ministry of Hajj and Umrah, 2019).

According to Al-ghalayini (2019), KSA has modernized the capacity of its airports and initiated its third expansion plan of the holy mosques. The transport system network has been reinforced to ease access and to enable pilgrims to complete their religious obligations conveniently. The 281 miles Mecca Medina Railway (The Haramain High-speed Railway) which links the two holy cities has been launched to safely mobilize the masses. Though the hospitality sector is an obvious beneficiary of a large captured religious travel market, other sectors including construction, aviation, catering, telecom, health, fast-moving consumer goods companies, and retail are all benefiting as well. Under the country's transformation program, the number of Hajj pilgrims is expected to reach 17 million by 2025 (Ladki \& Mazeh, 2017).

\subsection{Halal Tourism}

Halal Tourism is typically designed to increase tourist visits to destinations and attractions that have Islamic values (Jaelani, 2017); it includes food and daily life activities that are under the Islamic Law (Kamin, 2019). In Arabic, the word Halal means "permissible for Muslims". According to Loutfi (2017), Halal tourism means different things to different people. Halal tourism is perceived to provide pork and alcohol-free environment or sport amenities at hotels and beaches that provide gender exclusion. Turkey is one of the first countries providing halal hotels for Muslims. Halal tourism is not restricted to Middle Eastern countries, it is also present in selected European (Bosnia, Bulgaria, Cordoba (Spain), Cyprus, Herzegovina, Kazan (Russia), Malta, and Portugal) and Asian (Bangkok, Hong Kong, Indonesia, Japan, Malaysia, Singapore) cities and countries. 
Halal Tourism is not only of interest to the local businesses, but also it provides a platform to mitigate cultural and religious differences, advance globalization efforts, and bring in the always welcomed foreign exchange. In Spain, the average European tourists spend €980, the average Saudi spends €2287, the Egyptian $€ 1703$, Turks $€ 1501$ and Algerians $€ 1340$. It makes good business sense to provide Halal products to an affluent and culturally different market segment. According to Desilver and Masci (2017), there are 1.6 billion Muslims around the world. Without a doubt, most would be interested in becoming Halal tourists (business, or otherwise) when available. Indonesia's halal tourism industry not only attracts foreign tourists but also respond to domestic tourists' halal tourism needs (Jaelani, 2017). Five years since inception, Indonesia became ranked as the first world's Halal Tourism destination.

The majority of religious tourism in the Middle East is Halal (Hajj, Umrah, or the visit to specific religious sites). The development of Halal Tourism is essential because the benefits are realized by Muslim and non-Muslim travelers. Muslim tourists would enjoy the Halal privileges, and non-Muslim tourists appreciate being part of a culturally differentiated authentic tourism encounters.

\subsection{Regional Complementary Tourism Product of Jordan, Qatar, Dubai, and Abu Dhabi}

The rich cultural heritage of the above four states serves as a starting point to advance the region's tourism industries. The competitive positioning of the regional tourism industries has been supported by mega tourism development projects and diversified product offerings. All the above states have embarked on aggressive tourism development strategies to obtain a larger share of the region's growing travel markets. The four states have become mature pull market by themselves. They are capitalizing on the constant growth of regional religious tourism by offering complementary products and services. The below paragraphs report about the tourism product offering of Jordan, Qatar, Dubai, and Abu Dhabi.

\subsection{Jordan}

The 34,278 sq. miles kingdom is an ancient land with an active religious history. Though Jordan has many recognized biblical religious sites, the river of Jordan which is Jesus' baptismal place, is the most revered.

Historical, wellness and cultural tourism is the backbone of the Jordanian economy (Roberts, 2017). Such tourism is sustaining communities, creating employment opportunities, and most importantly bringing social stability. Being in the heart of the desert "Petra", dates back to the fourth situated in the state of Jordan (Lee, Boone, Adams, \& Hamilton, 2018). Petra has the potential for high unemployment, but because it is recognized on the Seven Wonders of the World list, unemployment was reduced. The Dead Sea has been attracting people for years. Visitors not only enjoy its stunning beauty, but also treat themselves to mud masks, salts bath, or float on the surface of the lowest body of wa- 
ter on earth (Rubin, 2017). The inventory of Jordan's cultural assets is quite extensive. The Kingdom's rich heritage, ancient roman ruins, and friendly welcoming people continue to be a premier destination that blends modernity with tradition.

\subsection{Qatar}

The rich oil and gas dessert peninsula whose capital is Doha was at one time a center of pearling and maritime trading. Qatar blends its modern architecture (Boulevard, magnificent high risers, residential housings, and shopping malls) with its pre-modern (old city centers, souks, and bazaars) lifestyle. Qatar's wealthy and visionary leadership has embarked on two internationally differentiated tourism initiatives, along with the establishment of numerous world-class museums, cultural entertainment centers, a concert hall, and an opera house.

The Pearl-Qatar, a multimillion-dollar 985 acres manmade island providing 12 miles of pristine beaches, numerous five stars hotels, world-class marines, residential spaces, unlimited dining, and entertainment (Clarks, 2007).

Qatar would soon be hosting the world's most popular sporting event (The 2022 FIFA World Cup), drawing millions of visitors and billions of television viewers. Qatar 2022 is a highly advertised world event. Where Doha would be the first Arab, Middle Eastern; and Muslim-majority country to ever host a tournament as big and as important as the FIFA World Cup. Eight world-class stadiums with a seating capacity of 360,000 spectators are in the process of being built. Luxurious world-class hotel towers are being built next to some of the stadiums, thus enabling hotel guests to enjoy live games. Millions are expected to be traveling in and out of Doha during the World Cup Season. Based on simulation studies from travelers and bloggers worldwide, it is estimated that the total expenses to attend any of Qatar's 2022 event would be around $\$ 7500$. To ensure the success of the events Qatar's airport has been expanded, and new railroad networks have been built. Similarly, through a collaborative initiative by various government agencies, Qatar development bank has launched a one-stop-shop center to provide know how to business operators and entrepreneurs on the ins and outs of starting a business in Qatar (Al-Khalifa, 2016; Aghadi, 2016). Qatar is on the right path of establishing a solid footprint on the region's tourism map.

\subsection{Dubai and Abu Dhabi}

The emirates of Dubai and Abu Dhabi's tourism profile is so differentiated and it includes religious, cultural, archeological, entertainment, shopping, and sport tourism assets. Tourists can enjoy a Bedouin camping tour and experience life as part of a desert tribe. Tourists can also enjoy falconry, horse riding, and camel racing that are still a key part of life (Roberts, 2017). In Dubai, people visit theme parks, historical sites, cultural events; and world-class shows, to be entertained and amused while in the city. Both Dubai and Abu Dhabi offer world-class tourism encounters and hospitality services that are not available anywhere else. 


\section{Challenges Confronting the Middle East Travel and Tourism Industries}

Though the Middle East has promising tourism potentials, the region has not been successful in achieving all of its targets. Middle Eastern cities offer the right product mix to attract all kinds of religious, cultural, recreational, environment and halal tourism; unfortunately, political unrest and terrorism continue to negatively affect the region and to slow down its tourism potentials. According to industry leaders, turbulence and political violence in the Middle East and North Africa has costed the region to loose around 7 million tourists last year (Bundhun, 2012). Political unrest could fairly be described as the biggest challenge that the area faces, especially due to the unrest that has been taking place for the past several years. Revolutions (Arab Springs) taking place in multiple countries all at once has also caused a sense of instability for the whole Middle East and North Africa.

KSA entry barriers continue to be high. Not all those who want to visit KSA are provided with visas. Though KSA is easing its entry barriers by increasing the number of issued visas, entry restrictions continue to exist on selected regional nationals. The absence of a unified Middle East entry visa, compel those who want to visit the region to pay additional visa fees for all of the countries that they like to visit. Similarly, it is very unfortunate that each of the identified Middle Eastern countries has its own currency. Thus, imposing on the tourists, additional financial currency conversion hardship.

Historically, KSA has only welcomed religious tourists. The 2030 vision has lifted entry barriers and is promoting the kingdom as a family attraction vacation destination. Though the cost of living in KSA and Jordan is quite reasonable, it is not the same for Dubai, Abu Dhabi, and Qatar. According to a 2018 Cost of Living Index published by Arab News, Dubai ranked first as the most expensive Arab city. The cost-of-its living index was 72.58 (Arab News, 2018). The cost of living provides an idea of how expensive or inexpensive tourism in a specific country is. In such a high cost of living, tourism may be perceived to be expensive, while on the contrary, it could be affordable, especially in the Gulf Countries. The reason for that and specifically that the Gulf Countries are more affordable is purely due to the high number of expats. The city receives millions of tourist's annually (Singh, 2016). Dubai's urban accommodation is so diverged from the world luxurious hotel (Burj Al Arab) to economy concepts where room rare ranges from $\$ 35$ - \$50 per night (Singh, 2016). The large expats' population enabled multinational corporations to be even more present in such countries. Multinational Corporations drums up more businesses and attract more investors into those countries. KSA and UAE set a great example for companies like Airbnb to become more and more popular.

Since the entry of Airbnb in the lodging business, the industry has revolutionized the way people reserve accommodation when traveling. Airbnb offers price sensitive services in comparison to classical hotels. However, according to 
Bloomberg, world Airbnb rental in Saudi Arabia, Kuwait, and the UAE were listed on the top 15 most expensive countries. Dubai and Riyadh (KSA's largest city) are extremely expensive cities that have the highest room rate prices (Karam, 2018).

Tourism in the Middle East has many potentials. All tourism players should find ways to address the region's tourism challenges and develop strategies to expedite the advancement of the regional tourism industries.

\section{Conclusion}

The MEA has not yet achieved its maximum tourism potentials. Demand for religious tourism in the Middle East will continue to increase. All tourism players have to find ways to provide world-class hospitality goods and services. Not all advancement in regional tourism industries has been supported by aggressive pro tourism legislative policies. Entry barriers should be lowered. A single tourist visa should be offered to all those who want to vacation in the Middle East.

Likewise, a single unified currency for all Middle Eastern countries will also ease tourist's quality of life. Travelers should not be subjected to various hidden costs when paying for hospitality goods and services with various currencies. Regional political stability, the continuous investment in tourism infrastructure, superstructure, and the maintenance of an acceptable cost of living index, are some of the variables that are holding down tourism advance in the region.

\section{Conflicts of Interest}

The authors declare no conflicts of interest regarding the publication of this paper.

\section{References}

300m Religious Tourists in the Middle East (2014). https://financialtribune.com/articles/travel/5492/300m-religious-tourists-in-middle-east-pa

Aghadi, H. (2016). The How-To: Starting Up a Business in Qatar. https://www.entrepreneur.com/amphtml/279624

Al Serkal, M. (2019). Look: UAE Satellite Snaps Photo of Makkah from Space. https://gulfnews.com/uae/science/look-uae-satellite-snaps-photo-of-makkah-from-spa ce-1.1558346811812

Al-ghalayini, B. (2019). Hajj and Umrah Investments-Meeting the Challenge. https://www.arabnews.com/node/1535186

Al-Khalifa, A. (2016). Qatar Development Bank Launches One Stop Shop Center for Small Business Needs. https://www.entrepreneur.com/article/283831

Arab News (2018). Dubai, Doha and Beirut Top List of Most Expensive Arab Cities. https://www.arabnews.com/node/1236666/offbeat

Badam, R. (2019). Everything We Know about the UAE's First Traditional Hindu Temple. https://www.thenational.ae/uae/heritage/everything-we-know-about-the-uae-s-first-tra ditional-hindu-temple-1.851155

Bremer, T. (2005). Tourism and Religion. Encyclopedia.com. 
https://www.encyclopedia.com/environment/encyclopedias-almanacs-transcripts-andmaps/tourism-and-religion

Bundhun, R. (2012). Unrest Spurs Tourism Challenges for Middle East and North Africa. https://www.thenational.ae/business/unrest-spurs-tourism-challenges-for-middle-eastand-north-africa-1.365809

Cartwright, M. (2018). Medieval Monastery. https://www.ancient.eu/Medieval Monastery

Cassaniti, J. (2015). Living Buddhism: Mind, Self, and Emotion in a Thai Community. Ithaca, NY, London: Cornell University Press. http://www.jstor.org/stable/10.7591/j.ctv2bctdt

CITC Deputy Governor (2019). CITC Deputy Governor: World Class ICT Services Ready for Hajj 2019 the Official Saudi Press Agency.

https://www.spa.gov.sa/viewfullstory.php?lang=en\&newsid=1953594

Clarks, E. (2007). The Pearl-Qatar: Multi-Billion Dollar Man-Made Island Home. https://newatlas.com/the-pearl-qatar-multi-billion-dollar-man-made-island-home/8065

Desilver, D., \& Masci, D. (2017). World Muslim Population More Widespread than You Might Think.

https://www.pewresearch.org/fact-tank/2017/01/31/worlds-muslim-population-morewidespread-than-you-might-think

Formula E Championship (2018-2019). Formula E Set to Revolutionize Motorsport Fans' Experience at Ad Diriyah E-Prix in Saudi Arabia. https://www.arabnews.com/node/1416126/saudi-arabia

Frost, N. (2019). The Multibillion Dollar Hajj Industry Is Getting Smarter than Ever. https://qz.com/1684679/the-hajj-pilgrimage-to-saudi-arabias-mecca-is-smarter-than-e ver/http://religioustravelplanningguide.com/top-10-pilgrimage-sites-middle-east

Gillett, K. (2019). Dubai's Quranic Park Named One of the World's Greatest Places by "Time" Magazine.

https://www.thenational.ae/lifestyle/travel/dubai-s-quranic-park-named-one-of-the-wo rld-s-greatest-places-by-time-magazine-1.902153

Jaelani, A. (2017). Halal Tourism Industry in Indonesia: Potential and Prospects. International Review of Management and Marketing, 7, 25-34.

https://doi.org/10.2139/ssrn.2899864

Jumali, E. (2018). Management of Hajj Funds in Indonesia. https://www.abacademies.org/articles/management-of-haij-funds-in-indonesia-7477.html

Kamin, D. (2019). The Rise of Halal Tourism. https://www.nytimes.com/2019/01/18/travel/the-rise-of-halal-tourism.html

Kapur, R. (2018). The Significance of Religious Tourism.

Karam, M. (2018). Business Real Estate News. Technology. Travel Guide. https://www.ameinfo.com/industry/travel/these-two-arab-countries-are-the-most-expe nsive-for-airbnb-listings

King, N. (2018). The GCC's Booming Religious Tourism Industry. https://gulfbusiness.com/gccs-booming-religious-tourism-industry

Kocyigit, M. (2016). The Role of Religious Tourism in Creating Destination Image: The Case of Konya Museum. International Journal of Religious Tourism and Pilgrimage, 4, Article 4. https://arrow.tudublin.ie/ijrtp/vol4/iss7/4

Ladki, S. M., \& Mazeh, R. A. (2017). Comparative Pricing Analysis of Mecca's Religious Tourism. International Journal of Religious Tourism and Pilgrimage, 5, 20-28. 
Lee, R., Boone, D., Adams, S., \& Hamilton, A. (2018). Petra.

https://www.history.com/topics/ancient-middle-east/petra

Loutfi, A. (2017). Halal Tourism Is a Booming Industry and Here's Why. https://mvslim.com/halal-tourism-uprising-new-industry

Major Religions of the World (2017). https://www.infoplease.com/world/religion/major-religions-world

Mashhad More than a Religious Destination (2017). https://financialtribune.com/articles/travel/68605/mashhad-more-than-a-religious-dest ination

Millington, A. (2019). The 19 Most Visited Cities around the World in 2019. https://www.businessinsider.com/most-visited-cities-around-the-world-ranked-2019-9

Ministry of Hajj and Umrah (2019). Strategic Partnerships. https://www.haj.gov.sa/en/InternalPages/Details/58

Mohiedin, A. (2020). https://newspaper.annahar.com/article/1118882

Revealed: The World's 20 Most Expensive Buildings (2016). https://www.telegraph.co.uk/travel/lists/the-worlds-most-expensive-buildings/masjid-a 1-haram-mecca-saudi-arabia

Roberts, K. (2017). How the Middle East Is Updating Its Vision for Cultural Tourists. https://www.thenational.ae/lifestyle/travel/how-the-middle-east-is-updating-its-visionfor-cultural-tourists-1.75824

Romain, J., Pepinster, C., \& Hasan, U. (2015). Why Is Jerusalem Important? You Asked Google-Here's the Answer.

https://www.theguardian.com/commentisfree/2015/may/20/why-jerusalem-importantgoogle-autocomplete

Rubin, S. (2017). Your Obsession with "Wellness" Is Killing the Dead Sea. https://www.thedailybeast.com/your-obsession-with-wellness-is-killing-the-dead-sea

Singh, N. (2016). How Much Does It Cost to Travel to Dubai-Love \& Road. https://loveandroad.com/how-much-does-it-cost-to-travel-to-dubai

Tala, M., \& Padurean, M. (2008). Dimensions of Religious Tourism. Amfiteatru Economic, 10, 242-253.

Thousands Flock to Dammam Demo (2019). https://airrace.redbull.com/en/news/thousands-flock-dammam-demo

Twaij, A. (2016). Religious Tourism Is Failing Iraq’s Economy. Ahmed Twaij. AW. https://thearabweekly.com/religious-tourism-failing-iraqs-economy

UAE's First Official Synagogue to Be Complete by 2022. https://www.dw.com/en/uaes-first-official-synagogue-to-be-complete-by-2022/a-50537 $\underline{493}$ 